\title{
Economic Value of Florida Water Resources: Valuing the Quality of Water for Household Needs ${ }^{1}$
}

\author{
Tatiana Borisova, Syed Irfan Ali Shah, Tara Wade, Xiang Bi, and Kelly Grogan²
}

\section{Introduction}

The goal of this publication is to provide water-resource professionals and interested citizens information regarding the value of improving and protecting the quality of domestic water supply using economic studies conducted in Florida. This information can be relevant, for example, when choosing whether to implement a costly source water protection program or whether to invest in improved tap water treatment technology. Is the public concerned about water quality characteristics? Are such investments justified? What are the benefits of the program or investment decision?

Note that the "value" is not the same as "price" or "cost," or, to quote Warren Buffett, "Price is what you pay; value is what you get" (cited from Town 2018). The price households pay for water is primarily determined by the cost of water treatment and delivery by a utility company. In contrast, the value is the benefits households derive from the improved water quality. However, to make investment decisions, it is essential to compare the costs and the benefits of a program or project. This article focuses on the benefits.

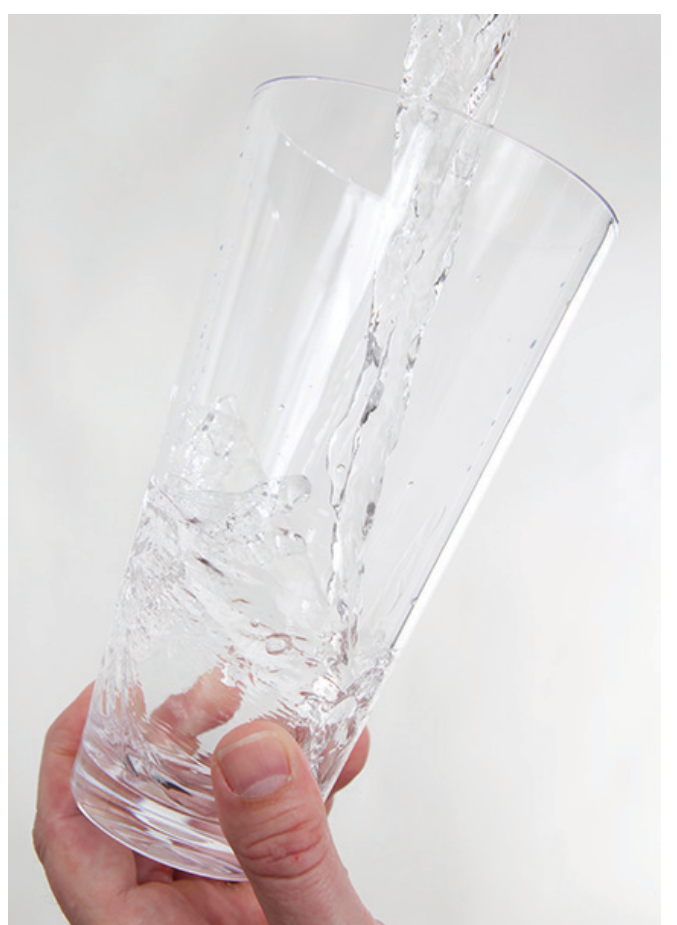

Figure 1. Drinking water is one of the key "goods and services" provided by Florida's water resources. Goods and services provided by nature are often referred to as "ecosystem services." Credits: Tyler Jones, UF/IFAS

1. This document is FE1059, one of a series of the Food and Resource Economics Department, UF/IFAS Extension. Original publication date May 2019. Visit the EDIS website at https://edis.ifas.ufl.edu for the currently supported version of this publication.

2. Tatiana Borisova, assistant professor and Extension specialist, Food and Resource Economics Department; Syed Irfan Ali Shah, project assistant; Tara Wade, assistant professor, Food and Resource Economics Department, UF/IFAS Southwest Florida Research and Education Center; Xiang Bi, assistant professor, Food and Resource Economics Department; and Kelly Grogan, associate professor, Food and Resource Economics Department; UF/IFAS Extension, Gainesville, FL 32611.

The Institute of Food and Agricultural Sciences (IFAS) is an Equal Opportunity Institution authorized to provide research, educational information and other services

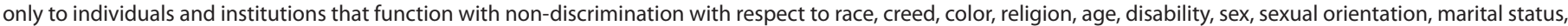

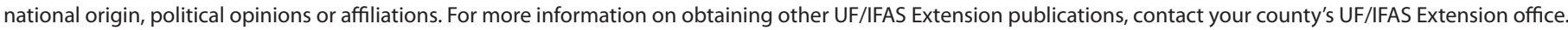
U.S. Department of Agriculture, UF/IFAS Extension Service, University of Florida, IFAS, Florida A \& M University Cooperative Extension Program, and Boards of County Commissioners Cooperating. Nick T. Place, dean for UF/IFAS Extension. 


\section{Household Water Supply in Florida}

In 2015,88 percent of Floridians received their water from the public supply, with the remaining 12 percent relying on domestic wells for both indoor and outdoor water uses. Note, however, in some counties, the proportion of people on domestic wells is much higher (e.g., almost 90 percent in Gilchrist and Union Counties). For both public supply and domestic wells, the source of water is groundwater (Dieter et al. 2018), indicating the importance of protecting this resource.

The Federal Safe Drinking Water Act provides the regulatory framework for protecting drinking water from source to tap (see more in Olexa et al. 2017), and Floridians are generally confident in the safety of their tap water at home (Center PIE 2015; Borisova et al. 2010). However, past studies also reported that residents might not be fully satisfied with the quality of their water (e.g., due to taste or odor) (Borisova et al. 2010). With proposals to expand the roster of contaminants to be regulated under the Safe Drinking Water Act and to increase the use of alternative water sources (e.g., stormwater or reclaimed water), analysis of public perceptions of drinking water quality and costs and benefits of water treatment will become more important.

\section{Are there many economic studies examining the value of drinking water quality?}

Are there many economic studies examining the value of drinking water quality? Because this publication is about Florida's water resources, we focus on the studies conducted in the state, with just a few examples from other states. Only three Florida-based economic studies examining the value of water quality for household needs were found (studies focused on tap water in Jacksonville, well water in Lake County, and forest management programs to protect source water quality throughout the state). This limited number indicates the need for additional research. We expect that the number of studies will increase because the topic is growing in importance. Combined water withdrawals for public supply and domestic wells accounted for $43 \%$ of total water withdrawals in Florida in 2015, and the withdrawals are projected to grow driven by population increase (EDR 2018). With increasing scarcity of fresh groundwater, the traditional source of water for public supply and other uses, economic analysis of the value of water for household and other needs will only increase in importance.

\section{What are the methods used to estimate the economic value of water?}

Economists use various ways, and they are described in "Valuing Florida's Water Resources: Ecosystem Services Approach." Methods mentioned in this publication are:

- The contingent valuation method relies on surveying people about a hypothetical market where the respondents can identify their willingness to pay (i.e., maximum price) for a good or service (Loomis and Walsh 1997). For example, the survey can ask respondents about their willingness to pay higher monthly water bills to allow their water supplier to invest in improving the quality of their tap water. The willingness to pay is an indicator of the value of the good or service to the respondent.

- The best-worst choice method also relies on a survey. It asks respondents to pick the most and least preferable (i.e., best and worst) characteristics of a product or program. For example, a survey can ask respondents about highest and lowest potential program cost, levels of water treatment, and the lead agencies to implement the program. Comparison of the answers indicates the tradeoffs people make among various characteristics, where price serves as an indicator of the value.

- The hedonic valuation method involves analyzing residential property sales prices to infer the value of the property characteristics, including the quality of well water, or proximity to a lake of good quality after all other house characteristics are accounted for. For example, for similar homes, sale prices can differ significantly if, for one house, records document problems with well-water quality.

\section{Measuring the Value of Tap Water Quality: Jacksonville, FL}

The perceptions and values of tap water quality in Jacksonville, FL, were examined by Chatterjee et al. (2017). Following regulatory requirements, the Jacksonville Electric Authority (JEA) monitors water quality by collecting and analyzing water samples and testing for more than 100 bacteriological and chemical components, with more than 45,000 water samples and tests typically conducted per year. "Most of the elements and minerals found in the drinking water occur naturally in the aquifer and they are suitable for drinking," stated JEA reports (p. 414, Chatterjee et al. 2017). Environmental Working Group (EWG), however, identified Jacksonville as the city with the 10th most polluted tap water (based on data for 2005-2009, compared with 99 other US cities with populations above 250,000) (Environmental Working Group 2009). JEA responded to 
this EWG conclusion by emphasizing that the EWG report misleadingly focused on the total number of water samples that tested positive for various compounds, and stated that because JEA tested frequently, there was a larger total number of violations in comparison with the utilities that tested less often. JEA also emphasized that federal and state water quality standards identify an acceptable percentage of positive detections that JEA generally meets.

Given public attention to the EWG's report and JEA's responses, Chatterjee et al. (2017) surveyed a sample of JEA customers and found that approximately one in every five respondents (or 22.5\%) experienced the smell of sulphur, and nearly one in every four respondents (or 28.7\%) worried about the health effects of poor water quality. The study used contingent valuation (CV) method (see a brief discussion above) with the willingness-to-pay (WTP) question, asking, "How much of an increase in your monthly water bill would you be willing to pay to improve the quality of your water $(\$ 15 ; \$ 10 ; \$ 5 ; \$ 3 ; \$ 2 ; \$ 0)$ ?" The estimated weighted average willingness to pay to improve the quality of tap water was $\$ 6.22$ per month. The study concluded that this amount could be added to the regular monthly water bill if JEA needed to invest in improving water-treatment infrastructure. Generalizing from this result, given that JEA supplies more than 240,000 customers, and assuming 50 percent of these customers are residential households (which is a conservative assumption), the willingness to pay for water-quality improvements among the JEA customers is $120,000 \times \$ 6.22=\$ 746,400$ monthly. The authors emphasized the preliminary nature of the estimates. Still, the results show a significant value that JEA customers assign to tap-water quality improvements. Note that the willingness to pay differed among households depending on their trust in authorities, their health concerns, their family compositions, and their education levels.

Similar studies were conducted in other states. For example, Tanellari et al. (2015) surveyed utility customers in suburbs of Washington, D.C. (in Virginia and Maryland), asking about their willingness to pay for programs that would either improve tap water quality (taste, odor, color, and safety), address pinhole leaks, or replace aged waterdistribution infrastructure. Customers' mean willingness to pay was the highest for the water quality program at $\$ 85.07$ per quarter (or approximately $\$ 28$ per month). Note, however, that the incomes and the size of the water bills differ between Washington, D.C., and Jacksonville, FL, and hence, the direct comparison of the estimates from the two studies may be misleading.

\section{Measuring the Value of Water Quality in Domestic Wells: Lake County, FL}

Guignet et al. (2016) examined the value assigned to water quality in domestic wells in rural Lake County. Instead of surveying households and asking about their willingness to pay (i.e., relying on the contingent valuation method employed by the studies described above), the authors related the residential property sale prices to well water quality information (i.e., the hedonic valuation method). Water-quality indicators used were total nitrate and nitrite, ethylene dibromide, and arsenic, all pollutants that can be linked to agricultural pollution runoff. The authors found that the houses with wells for which water-quality problems were reported were selling for lower prices. Finding contamination within three years before the sale resulted in a 2 to 6 percent decline in the property prices. In other words, given the mean residential property price of $\$ 258,000$, the reduction in the sale price was between $\$ 5,200$ and $\$ 15,500$. For total nitrate and nitrite specifically, there was no statistically significant effect on the property sale prices until the reported concentration reached the health-based regulatory limits. Once total nitrate and nitrite concentration exceeded the health-based limit, there was significant reduction in property value. At total nitrate and nitrite concentrations twice exceeding the regulatory limits, the estimated reduction in property values was $7-15$ percent or $\$ 17,900-\$ 38,900$. Overall, the study shows that contamination influences home prices (and sales taxes and potentially the health of the residents); however, home prices rebound after a time once the contamination issue is resolved.

\section{Measuring the Value of Protecting Our Water Supplies: Forest Management Programs}

Most tap water in Florida and all water in our domestic wells originates from groundwater reserves called aquifers. Aquifers are "underground, porous rocks that hold water and allow water to move through the holes within the rock" (SJRWMD 2018). Aquifers are the source of water supply for almost everyone in northeast and east-central Florida and for a large portion of people in the rest of the state. Protecting aquifers means protecting our future water supply.

Different strategies have been used to protect Florida's aquifers, and one of them focuses on Florida's forest management. Forests have been shown to improve and protect 
water quality by minimizing soil erosion and trapping water pollutants (FAO 2018). Forests also provide a variety of other ecosystem services. Kreye et al. (2016) used the best-worst estimation method to examine public preferences for clean water benefits (e.g., recreation and drinking water resources) provided by forest protection programs. The study found that Floridians value the benefits from forest/water protection programs at \$154-230 million (annual average). The study also showed that Floridians have preferences for conservation easement programs that can protect forested lands (as compared with the other programs such as providing information to landowners to help better manage forests and safeguard water resources).

\section{Summary}

Studies reviewed in this article provide examples of the value that Floridians assign to maintaining or improving the quality of the water supply. These examples demonstrate that investments in protecting or enhancing tap water quality, as well as in protecting water supply sources, can be justified by increased benefits derived by the public. The number of studies examining the value of tap- or well-water quality is limited, indicating the need for more research in this area. With water suppliers analyzing alternative water supplies such as stormwater, aquifer storage and recovery, and reclaimed water to meet the demand of growing population, public perceptions and values assigned to different attributes of tap or well water will continue to be a hot topic for research and policy discussions. Potential directions for future studies include:

\section{- Public perception of the quality of tap and well water in} various Florida regions

Public opinions and concerns may differ among regions due to differences in source water quality, the age of drinking water infrastructure, or characteristics of the customers surveyed, such as income levels, family structure, age, etc. Opinions and concerns may also change over time. Therefore, continuous monitoring of public opinion is necessary to prioritize issues to be addressed by water suppliers and local government agencies.

\section{- The value of water supplied from various sources}

Several pilot projects currently examine the potential of direct potable reuse of reclaimed water, that is, the use of treated wastewater for drinking without an environmental buffer (e.g., releasing treated wastewater into a river, and then withdrawing water from the river). There are also pilot studies that include treated stormwater as a water source. With these alternatives added to the mix of traditional surface and groundwater sources, the value that customers may assign to the characteristics of the water and its treatment may be used to guide suppliers' selection of water sources and water-treatment technologies.

\section{References}

Borisova, T., J. Brett, and C. Gardner. 2010. Public opinion about drinking water issues in Florida. FE843. Gainesville: University of Florida Institute of Food and Agricultural Sciences. http://edis.ifas.ufl.edu/fe843

Center for Public Issues Education (Center PIE). 2015. Public opinions of water quantity \& quality [online] Available at: http://www.piecenter.com/issues/water/water/

Chatterjee, C., R. Triplett, C. K. Johnson, and P. Ahmed. 2017. "Willingness to pay for safe drinking water: A contingent valuation study in Jacksonville, FL." Journal of environmental management 203 pp. 413-421.

Dieter, C. A., K. S. Linsey, R. R. Caldwell, M. A. Harris, T. I. Ivahnenko, J. K. Lovelace, M. A. Maupin, and N. L. Barber. 2018. Estimated Use of Water in the United States CountyLevel Data for 2015 (ver. 2.0, June 2018): U.S. Geological Survey data release, https://doi.org/10.5066/F7TB15V5

Economic and Demographic Research (EDR). 2018. Natural Resources and Infrastructure. [online] Available at: http://edr.state.fl.us/Content/natural-resources/index.cfm [Accessed 27 Jul. 2018].

Environmental Working Group. 2009. Environmental Working Group National drinking water database http:// www.ewg.org/tap-water/ [accessed 1 Jan. 2017].

Food and Agriculture Organization of the United Nations (FAO). 2018. Forests and water quality [online] Available at: http://www.fao.org/in-action/forest-and-water-programme/ en/ [Accessed 23 Apr. 2019]

Guignet, D., P. Walsh, and R. Northcutt. 2017. "Impacts of Ground Water Contamination on Property Values: Agricultural Run-off and Private Wells." Agricultural and Resource Economics Review 45, Special Issue 2, 293-318.

Kreye, M. M., D. C. Adams, F. J. Escobedo, and J. R. Soto. 2016. "Does policy process influence public values for forest-water resource protection in Florida?" Ecological Economics 129 pp.122-131. 
Loomis, J. B., and R. G. Walsh. 1997. Recreation economic decisions; comparing benefits and costs (No. Ed. 2). Venture Publishing Inc.

Olexa, M., T. Borisova, and J. Davis. 2017. Handbook of Florida water regulation: Safe Drinking Water Act. FE587. Gainesville: University of Florida Institute of Food and Agricultural Sciences. http://edis.ifas.ufl.edu/fe587

SJRWMD. 2018. Florida's aquifers - SJRWMD. [online] Available at: https://www.sjrwmd.com/water-supply/ aquifer/ [Accessed 27 Jul. 2018].

Tanellari, E., D. Bosch, K. Boyle, and E. Mykerezi. 2015.

"On consumers' attitudes and willingness to pay for improved drinking water quality and infrastructure." Water Resources Research 51(1) pp.4757.

Town, P. 2018. The Important Differences between Price And Value. Forbes Community Voice, Post from Jan. 4, 2018. https://www. forbes.com/sites/forbesfinancecouncil/2018/01/04/ the-important-differences-between-price-and-value 